\title{
Biases in relative estimates of dietary mineral status from esophageal extrusa
}

\author{
W. E. PINCHAK, L. W. GREENE, AND L. J. HUNT
}

\section{Abstract}

An experiment was conducted to determine whether or not the effects of forage type and time into feeding period precluded use of esophageal extrusa to estimate relative dietary mineral status of cattle. Four esophageally fistulated Angus-Hereford $x$ Jersey crossbred steers (340 to $545 \mathrm{~kg}$.) were alternately fed Coastal bermudagrass hay (Cynodon dactylon) (BGH) and fresh greenchopped, TAM 105, wheat (Triticum aestivum) (GCW). Extrusa was sampled at 5 and 20 minutes into the feeding period. Significant additions of $\mathrm{Na}, \mathrm{P}$, and $\mathrm{K}$ occurred in the extrusa of both forages. Ash, $\mathrm{Mg}$, and $\mathrm{Ca}$ concentrations were higher in the extrusa of BGH. Calcium, $\mathrm{Zn}$, and $\mathrm{N}$ concentrations were similar in extrusa of both forages. Changes in $\mathrm{Na}, \mathrm{P}$, ash, $\mathrm{Ca}$, and $\mathrm{Mg}$ concentrations were as expected; however, the changes in $\mathrm{K}, \mathrm{Cu}$, and $\mathrm{Zn}$ disagree with published results. Previous research suggested $\mathrm{K}, \mathrm{N}, \mathrm{Ca}, \mathrm{Cu}$, and $\mathrm{Mg}$ content of the diet could be estimated from esophageal extrusa. The current experiment indicated dietary $\mathrm{Cu}, \mathrm{Mg}$, and $\mathrm{K}$ content of diets could not be extrapolated from extrusa concentrations of these minerals.

Forage type had significant effects on the extent and form of change in the associated extrusa. The magnitude of these effects precludes use of esophageal extrusa for relative comparisons among plant communities within and among seasons, if selected forages are markedly different in maturity, moisture content, and physical form. Time into feeding period had no detectable effect on amount or percent of change in extrusa from the forage.

Key Words: forage type, macrominerals, microminerals

Range and pasture forages are at least seasonally deficient in one or more essential minerals (Green et al. 1987, Kalmbacher 1983, Knebusch et al. 1986, McDowell et al. 1984, Murray et al. 1978) relative to projected beef cattle requirements (NRC 1984). The development of cost effective mineral supplementation strategies for free ranging livestock is dependent upon knowledge of the spatial and temporal distribution of these deficiencies.

Unfortunately, quantitative assessment of such deficiencies are difficult because the combined effects of mastication, salivation, and leaching preclude quantitative recovery of dietary ash and its associated mineral matrix from esophageal extrusa (Wallace et al. 1972, Lesperance et al. 1974, Scales et al. 1974, Little 1975, Hart 1983). Over a wide range of conserved forages significant additions of sodium $(\mathrm{Na})$, chloride $(\mathrm{Cl})$, phosphorus $(\mathrm{P})$, zinc $(\mathrm{Zn})$, and cobalt (Co) have been documented (Hoehne et al. 1967, Little 1972 and 1975, Mayland and Lesperance 1977, Lesperance et al. 1974) while the concentrations of calcium $(\mathrm{Ca})$, magnesium $(\mathrm{Mg})$, copper $(\mathrm{Cu})$, and potassium $(\mathrm{K})$ were lower to unchanged in extrusa.

Despite these findings Kalmbacher et al. (1984) assumed esophageal extrusa could be used for making relative comparisons of the dietary mineral status of cattle over a wide range of forage types

Authors are assistant professor and technician, Texas Agriculture Experiment Station, Vernon 76384; associate professor, Department of Animal Science, Texas A\&M University, College Station 77843, respectively.

Appreciation is expressed to the E. Paul and Helen Buck Waggoner Foundation for partial funding of this research.

Report is published with approval of the Director, Texas Agriculture Experiment Station as TA-23923.

Manuscript accepted 9 May 1989 (plant communities), seasons (plant maturity), and management strategies (grazing systems) in a given location. However, for this approach to be valid in multispecies rangeland environments, it must be assumed that the extent of salivary mineral adulteration is comparatively constant across forage species and season. Furthermore, it must be assumed that salivary adulteration is relatively constant throughout a collection period. To examine the validity of these assumptions, we conducted an experiment under controlled feeding conditions to quantify the effects of forage type and length of feeding period on change in extrusa mineral concentrations.

\section{Experimental Procedure}

Four esophageally fistulated Angus-Hereford $x$ Jersey crossed steers $(340$ to $545 \mathrm{~kg}$ ) were housed in a common, covered pen and maintained at ad libitum levels on a Coastal bermudagrass hay for 7 days prior to and throughout the 5 consecutive 1-day trials. Animals had continuous access to water but were offered no supplemental mineral during this time.

During each trial steers were alternately fed Coastal bermudagrass hay (Cynodon dactylon) (BGH) and fresh green-chopped, variety TAM 105 wheat (Triticum aestivum) (GCW) (Table 1).

Table 1. Percent dry matter (DM), ash, and mineral composition of forages.

\begin{tabular}{lccccc}
\hline \hline & \multicolumn{2}{c}{ Bermudagrass hay } & & \multicolumn{2}{c}{ Green chopped wheat } \\
\cline { 2 - 3 } \cline { 6 - 6 } Item & Mean & SD' & & Mean & SD \\
\hline DM (\%) & 88.46 & 2.44 & & 42.35 & 1.87 \\
Ash (\%) & 9.12 & .9 & & 13.91 & 1.51 \\
Na (\%) & .09 & .01 & & .09 & .03 \\
K (\%) & 1.21 & .34 & & 1.22 & .58 \\
P (\%) & 1.48 & .45 & & 2.39 & .20 \\
Ca (\%) & .34 & .03 & & .19 & .01 \\
Mg (\%) & .19 & .03 & & .14 & .01 \\
N (\%) & 1.78 & .29 & & 3.57 & .25 \\
Cu ppm & 2.20 & .37 & & 5.50 & .42 \\
Zn ppm & 15.50 & 6.13 & & 19.50 & 2.97 \\
\hline
\end{tabular}

'SD - Standard deviation of the mean, $n=5$.

Forages were fed out of 56.8-1 rubber tubs to decrease the risk of exogenous mineral contamination. Steers were tethered and allowed to eat a forage for 5 minutes during which all extrusa was collected in standard screen-bottom collection bags. Animals were then permitted to eat for another 10 minutes during which the extrusa was discarded. Animals then ate for another 5 minutes, and all extrusa was retained. The steers were then fasted for 30 minutes and the process was repeated using the other forage. In this manner 4 samples of each forage time period combination (4) were collected per trial (5). Screen-bottom bags were used to emulate field sampling techniques.

Following field sampling, extrusa and forage samples were frozen and then sub-sampled and(or) lympholized to constant weight. Samples were ground to pass a 1-mm mesh screen (No. 4 Wiley Mill). Forage and extrusa subsamples were then either analyzed for organic matter, ash, and kjeldahl N (AOAC 1975) or dry ashed 
for $12 \mathrm{hr}$ at $550^{\circ} \mathrm{C}$. The ash was then digested for $24 \mathrm{hr}$ in $20 \mathrm{ml}$ of $20 \% \mathrm{HNO}_{3} \mathrm{HCL}(2: 1)$ solution; and sodium $(\mathrm{Na})$, calcium $(\mathrm{Ca})$, potassium (K), magnesium $(\mathrm{Mg})$, zinc $(\mathrm{Zn})$, and copper $(\mathrm{Cu})$ concentrations were determined with atomic absorption spectrophotometry (Varian A-6), and phosphorus (P) concentrations were determined by a colormetric technique (Fiske and Subbarow 1925). All values are presented on a DM basis.

\section{Data Analyses}

A paired $t$-test was employed to determine if ash and $\mathrm{N}$ content of extrusa varied significantly between each forage. The forage concentration was subtracted from the extrusa concentration of each constituent, and the difference was tested against the null hypothesis of no change. A randomized complete block $2 \times 2$ factorial arrangement of treatments analysis of variance model was utilized to test for the quantitative changes due to forage type and time into feeding period. Animals formed blocks with forage type (F), time into feeding period (T), and the $\mathrm{F} \times \mathrm{T}$ factorial arranged within each block. A protected Student-Neuman-Keuls means separation test was used for posthoc comparisons.

\section{Results and Discussion}

Green-chopped wheat was higher in ash, $\mathrm{K}, \mathrm{P}, \mathrm{N}, \mathrm{Cu}$, and $\mathrm{Zn}$ than BGH (Table 1). Conversely, BGH was higher in dry matter (DM), $\mathrm{Ca}$, and $\mathrm{Mg}$. Forage $\mathrm{Na}$ concentrations were similar. Concentrations of $\mathrm{Na}, K$, and $P$ in extrusa of both forages were significantly $(P<10)$ greater than in the forages (Table 2). Associated

Table 2. Quantitative and percent change in the mineral, nitrogen and ash contents of extrusa from that of forage.

\begin{tabular}{|c|c|c|c|c|c|c|}
\hline \multirow[b]{3}{*}{ Item } & \multicolumn{6}{|c|}{ Forage } \\
\hline & \multicolumn{3}{|c|}{ Bermudagrass hay } & \multicolumn{3}{|c|}{ Green chopped wheat } \\
\hline & $\Delta^{\mathrm{a}}$ & $\mathbf{p}^{b}$ & $\Delta \%^{\mathrm{c}}$ & $\Delta^{\mathrm{a}}$ & $\mathbf{p}^{\mathbf{b}}$ & $\Delta \%^{\mathrm{c}}$ \\
\hline Ash (\%) & 2.38 & .01 & 26 & .26 & .17 & 2 \\
\hline $\mathrm{Na}(\%)$ & .95 & .01 & 1063 & .77 & .01 & 867 \\
\hline K $(\%)$ & 25 & .08 & 21 & 1.51 & .01 & 124 \\
\hline $\mathrm{P}(\%)$ & 1.21 & .01 & 81 & .56 & .01 & 24 \\
\hline $\mathrm{Ca}(\%)$ & .01 & .14 & -1 & .01 & .78 & -1 \\
\hline $\operatorname{Mg}(\%)$ & -.02 & .05 & -8 & 0 & .96 & -12 \\
\hline $\mathbf{N}(\%)$ & .01 & .81 & $>1$ & -.04 & .14 & -1 \\
\hline $\mathrm{Cu}$ (ppm) & 1.30 & .01 & 60 & -.24 & .41 & $\begin{array}{l}-1 \\
-4\end{array}$ \\
\hline $\mathrm{Zn}(\mathrm{ppm})$ & -1.20 & .18 & -7 & 2.50 & .17 & 13 \\
\hline
\end{tabular}

$\Delta=$ Extrusa $[\bar{X}]-$ Forage $[\bar{X}]$.

b Probability that $\Delta=0$

${ }_{\Delta \%}=\Delta /$ Forage $\bar{X} * 100$

percentage increases ranged from 867 to $1,063 \%, 24$ to $81 \%$, and 21 to $124 \%$ in $\mathrm{Na}, \mathrm{P}$, and $\mathrm{K}$, respectively. Significant increases of $\mathrm{Na}$ and $P$ have been reported previously (Church 1976, Little 1972, Hoehne et 1967, Mayland and Lesperance 1977) for rumen extrusa whereas only a slight $(-2 \%$ to $4 \%$ ) change in $\mathrm{K}$ content has been reported previously (Mayland and Lesperance 1977, Lesperance et al. 1974). The causes of these discrepancies are unclear though differences in site of extrusa collection (rumen versus esophageal fistula) may be a factor. The possibility also exists that the animals in this experiment were in a negative $\mathrm{Na}$ balance, thus $\mathrm{K}$ content of the saliva was greater (Church 1976) than in previous research. Based upon salivary concentrations of $\mathrm{Na}, \mathrm{P}$, and $\mathrm{K}$ (McDougall 1948), observed changes in their respective extrusa concentrations were not unexpected.

Calcium and $\mathrm{N}$ concentrations were unchanged to slightly less in extrusa and did not differ from concentrations in either forage (Table 2). Minimal changes in extrusa $\mathrm{Ca}$ and $\mathrm{N}$ content are consistent with previous findings (Lesperance et al. 1974). Ash and $\mathrm{Cu}$ concentrations in BGH extrusa were significantly greater ( $26 \%$ and $60 \%$, respectively) than in $\mathrm{BGH}$, whereas concentrations of
$\mathrm{Mg}$ and $\mathrm{Zn}$ were significantly less in BGH extrusa $(8 \%)$ than in $\mathrm{BGH}$. Magnesium, $\mathrm{Zn}, \mathrm{Cu}$ concentrations, and ash content of GCW extrusa did not differ from fed GCW. The magnitude of change in $\mathrm{Cu}$ concentrations of $\mathrm{BGH}$ extrusa disagree with previous results where no change in $\mathrm{Cu}$ concentration in extrusa from the fed forage was detected (Little 1975). Unlike previous reports, there was no significant increase for either forage in extrusa $\mathrm{Zn}$ levels (Little 1975, Mayland and Lesperance 1977).

\section{Effect of Forage Type and Time into Feeding Period}

Forage type significantly affected magnitude of change in concentration of all constituents in extrusa except $\mathrm{Ca}$ and $\mathrm{N}$ (Table 3). Since there was no difference between extrusa and forage $\mathrm{Ca}$ and $\mathrm{N}$ concentrations (Table 2), it would appear salivation, mastication, and leaching do not significantly alter forage $\mathrm{Ca}$ and $\mathrm{N}$ contents.

Salivary additions of ash and $P$ to $B G H$ were significantly greater than for GCW (Table 3). This may be attributed to the

Table 3. Effects of forage type, length of feeding period and the $F \times T$ interaction on the quantitative change in extrusa versus forage mineral, ash and nitrogen concentrations.

\begin{tabular}{|c|c|c|c|c|c|}
\hline \multirow[b]{2}{*}{ Item } & \multicolumn{2}{|c|}{ Forage } & \multicolumn{2}{|c|}{$\begin{array}{c}\text { Time into } \\
\text { feeding period }\end{array}$} & \multirow[t]{2}{*}{$\mathbf{F} \times$} \\
\hline & $\begin{array}{c}\text { Bermuda- } \\
\text { grass } \\
\text { hay }\end{array}$ & $\begin{array}{l}\text { Green } \\
\text { chopped } \\
\text { wheat }\end{array}$ & 5 & 20 & \\
\hline $\operatorname{Ash}(\%)$ & $2.38^{a}$ & $.26^{\mathrm{b}}$ & $1.20^{\circ}$ & $1.50^{\circ}$ & $\mathbf{N S}^{1}$ \\
\hline $\mathrm{Na}(\%)$ & $.95^{a}$ & $.77 b$ & $.87^{a}$ & $.85^{b}$ & NS \\
\hline $\mathrm{K}(\%)$ & $.25^{a}$ & $1.51^{\mathrm{b}}$ & $.90^{2}$ & $.85^{\mathrm{a}}$ & NS \\
\hline $\mathrm{P}(\%)$ & $1.21^{\mathrm{a}}$ & $.56^{\mathrm{b}}$ & $.86^{\mathrm{a}}$ & $.91^{\mathrm{a}}$ & NS \\
\hline $\mathrm{Ca}(\%)$ & $.01^{a}$ & $<.01^{a}$ & $<.01^{\mathrm{a}}$ & $<.01^{\mathrm{a}}$ & NS \\
\hline $\operatorname{Mg}(\%)$ & $-.02^{\mathrm{a}}$ & $<.01^{b}$ & $<.01^{a}$ & $<.01^{\mathrm{a}}$ & NS \\
\hline $\mathbf{N}(\%)$ & $.06^{\mathrm{a}}$ & $-.25^{\mathrm{a}}$ & $-.17^{\mathrm{a}}$ & $-.03^{a}$ & NS \\
\hline $\mathrm{Cu}(\mathrm{ppm})$ & $1.30^{\mathrm{a}}$ & $-.24^{b}$ & $.66^{\mathrm{a}}$ & $.39^{\mathrm{a}}$ & NS \\
\hline $\mathrm{Zn}(\mathrm{ppm})$ & $-1.20^{\mathrm{a}}$ & $2.50^{\mathrm{b}}$ & $.10^{\mathrm{a}}$ & $.10^{\mathrm{a}}$ & $*$ \\
\hline
\end{tabular}

a,b Means within a row within forage and length of feeding followed by different letters are significantly different at $P<.10$.

${ }^{1}$ NS $=$ non significant $P>.10^{*}=$ significant interaction effect at $P<.10$.

greater dry matter content of BGH causing increased salivary flow (Lesperance et al. 1974), increased handling time in bolus formation (Church 1976), and increased absorption of saliva (Wallace et al. 1972).

Salivary $\mathrm{K}$ contribution to GCW extrusa was 5 times greater than to BGH extrusa. Mayland and Lesperance (1977) found no difference in the percent change of $K$ in rumen extrusa between grass and alfalfa hays; however, combined across both hays, a significant $7 \%$ increase in extrusa $\mathrm{K}$ existed. Because $\mathrm{K}$ is the third most abundant cation in saliva (McDougall 1948, Church 1976), K additions to extrusa should respond to forage type in a manner similar to $\mathrm{Na}$ and $\mathrm{P}$. However, $\mathrm{K}$ additions were greater in GCW than BGH, exactly opposite of $\mathrm{Na}$ and $\mathrm{P}$ trends. The reasons for this discrepancy are not readily apparent from this experiment or from previous reports. However, GCW may have stimulated greater secretion of saliva from nonparatoid salivary glands having higher concentrations of K (Church 1976).

Extrusa of BGH exhibited an $8 \%$ decrease in $\mathrm{Mg}$, whereas no change was detected in $\mathrm{Mg}$ concentrations of GCW extrusa thus agreeing with the findings of Little (1975) that $\mathrm{Mg}$ content of extrusa does not differ from forage consumed. Conversely, forage type had a significant $(P<.10)$ affect on changes in extrusa $\mathrm{Cu}$ levels. Extrusa $\mathrm{Cu}$ concentrations were $60 \%$ greater than in $\mathrm{BGH}$ and $4 \%$ less than in GCW. This contrasts with previous results (Little 1975) which indicated $\mathrm{Cu}$ concentrations in extrusa did not differ from forage concentrations over a wide range of forage types. Copper levels increased in BGH extrusa yet decreased or 
remained unchanged in $\mathrm{GCW}$. This suggests that $\mathrm{Cu}$ is a minor constituent of saliva that can significantly bias dietary $\mathrm{Cu}$ estimates when mature forages are consumed.

Quantitatively different changes in extrusa $\mathrm{Zn}$ concentrations occurred between BGH and GCW. As discussed above, the percentage changes caused by salivary $\mathrm{Zn}$ contamination were markedly less than the $22 \%$ to $75 \%$ increases previously reported (Little 1975 , Mayland and Lesperance 1977) (Table 3). Zinc concentrations were not significantly $(P>.15)$ altered in the extrusa of either forage. However, change in $\mathrm{Zn}$ concentration was significantly $(P<0.10)$ greater for GCW $(13 \%)$ than BGH $(-7 \%)$ extrusa. The use of screen-bottomed collection bags in this experiment would have promoted more leaching and drainage losses than using polyethylene collection bags (Little 1975) or rumen evacuation (Mayland and Lesperance 1977). Hence, these discrepancies may have resulted from differential leaching of forage $\mathrm{Zn}$ and(or) salivary $\mathrm{Zn}$ loss through drainage.

Type of saliva produced and secretion rates change as cattle shift from resting to eating and as the feeding period progresses (Church 1976). Hence, the potential for differential contamination of extrusa exists. However, in this experiment, samples taken from 0 to 5 and from 15 to 20 minutes into the feeding period had no detectable effect on extent of salivary contamination for any constituent examined (Table 3). Similarly, there were no significant interaction effects of $F \times T$ for any constituents except $\mathrm{Zn}$. Salivary $\mathrm{Zn}$ contribution increased with duration of feeding period in GCW, but the salivary contribution decreased in BGH extrusa. Differential loss of salivary $\mathrm{Zn}$ from screen bottom bags caused by forage type and form may partially explain this difference.

\section{Conclusions}

We concluded from these and previously reported results the effects of mastication, salivation, and leaching associated with ingestion of forage precludes quantitative recovery from extrusa of dietary ash, $\mathrm{Na}, \mathrm{P}, \mathrm{K}$, and $\mathrm{Cu}$. Conversely, dietary $\mathrm{Ca}, \mathrm{N}$, and probably $\mathrm{Mg}$ can be reasonably well estimated from extrusa. Extrusa $\mathrm{Zn}$ concentrations did not differ significantly from forage concentrations and would appear estimatable for single forage diets but would not be from more complex diets because of differential changes related to species and maturity.

These results would suggest that the validity of the assumptions of Kalmbacher et al. (1984) are at best suspect. The forages used in the present experiment represent a range in plant maturity and species that would occur within and among seasons for a number of locations. Therefore, we find no indication that valid comparisons of the mineral quality of cattle diets is possible with this approach. Reconstruction of the mineral profile of cattle diets (Pinchak et al. 1989) based upon species composition and mineral content of live and dead tissue of species, is a biologically realistic and feasible alternative to relative or whole plant estimates of mineral content.

\section{Literature Cited}

AOAC 1975. Official methods of analysis (13th Ed.) Assoc. Offic. Agr. Chem., Washington, D.C.

Church, C.D. 1976. Digestive physiology and nutrition of ruminants. Vol. 1. Digestive physiology. 2nd edition. O\&B Books Corvalis, Ore.

Fiske, C.A., and I. Subbarow. 1925. The colorimetric determination of phosphorus. J. Biol. Chem. 66:375.

Greene, L.W., W.E. Pinchak, and R.K. Heitschmidt. 1987. Seasonal dynamics of minerals in forages at the Texas Experimental Ranch. $J$. Range Manage. 40:502-506.

Hart, R.H. 1983. Correcting for salivary contamination of esophageal fistula samples. J. Range Manage. 36:119.

Hoehne, O.E., D.C. Clanton, and C.L. Streeter. 1967. Chemical changes in esophageal fistula samples caused by salivary contamination and sample preparation. J. Anim. Sci. 26:628.

Kalmbacher, R.S., K.R. Long, and F.G. Martin. 1984. Seasonal mineral concentration in diets of esophageally fistulated steers on three range areas. J. Range Manage. 37:36.

Kalmbacher, R.S. 1983. Distribution of dry matter and chemical constituents in plant parts of four Florida native grasses. J. Range Manage. 36:298-301.

Knebusch, C.F., J.L. Valdes, L.R. McDowell. 1986. Macromineral status and supplementation of grazing steers under tropical conditions in Guatemala. Nutr. Rep. Int. 33:917-929.

Lesperance, A.L., D.C. Clanton, A.B. Nelson, and C.B. Theurer. 1974. Factors affecting the apparent chemical composition of fistula samples. Western Regional Coordinating Comm. \#8 T18 p. 29.

Little, D.A. 1972. Studies on cattle with oesophageal fistulae. The relation of the chemical composition of feed to that of the extruded bolus. Austr. J. Exp. Agr. Anim. Husb. 12:126.

Little, D.A. 1975. Studies on cattle with oesophageal fistulae: comparison of concentrations of mineral nutrients in feeds and associated boluses. Austr. J. Exp. Agr. Anim. Husb. 15:437.

Mayland, H.F. and A.L. Lesperance. 1977. Mineral composition of rumen fistula samples compared to diet. J. Range Manage. 30:388.

McDougall, E.I. 1948. Studies of ruminal saliva. I. the composition and output of sheep saliva. Biochem. J. 43:99-109.

McDowell, L., J.H. Conrad, and G.L. Ellis. 1984. Mineral deficlencies and imbalances and their diagnosis. In: I.M.C. Gilchrist and R.I. Mackie (eds.) Herbivore Nutrition in the Subtropics and Tropics. pp. 67-88. The Science Press (PTY) Ltd. Craighall, South Africa.

Murray, R.B., H.F. Mayland, and P.J. Van Soest. 1978. Growth and nutritional value to cattle of grasses on cheatgrass range in southern Idaho. USDA. Forest Service Res. Paper Int. 199.

NRC. 1984. Beef cattle requirements 5 th Edition. Nat. Acad. Sci., Natural Nutrient Requirements Committee. Washington, D.C.

Pinchak, W.E., L.W. Greene, and R.K. Heitschmidt. 1989. Estimated mineral concentrations in beef cattle diets from a southern mixed-grass prairie. J. Range Manage. 42:431-433.

Scles, G.H., C.L. Streeter, A.H. Denham, and G.M. Ward. 1974. Effect of mastication, salivary contamination and leaching on the chemical composition of forage samples collected via esophageal fistulae. J. Anim. Sci. 38:1278.

Wallace, J.D., D.N. Hyder, and G.M. Van Dyne. 1972. Salivary contamination of forage selected by esophageal fistulated steers grazing sandhill grassland. J. Range Manage. 25:184. 